Original Article

\title{
The Effect of Spiritual Guidance of Reproductive Health By Booklets on The Changes of Adolescent's Attitudes: Dating Status in Premarital Sexual Behavior
}

\author{
Sitawati $^{1}$, Suriah ${ }^{2}$, Saidah Syamsuddin ${ }^{3}$, Sutinah Made ${ }^{4}$, Werna Nontji ${ }^{3}$, \\ Muhammad Tamar ${ }^{3}$ \\ ${ }^{1}$ Midwifery Study Program, Postgraduate School, Hasanuddin University, Makassar \\ ${ }^{2}$ Faculty of Public Health, Hasanuddin University, Makassar E \\ ${ }^{3}$ Faculty of Medicine, Hasanuddin University, Makassar \\ ${ }^{4}$ Faculty of Fisheries and Marine Affairs, Hasanuddin University, Makassar
}

(sitawati19p@student.unhas.ac.id / 08224734 6655)

\begin{abstract}
The spiritual guidance of reproductive health and safety is oriented towards strengthening moral and religious values in addressing adolescent reproductive health problems with an approach on several aspects, such as preventive, curative, rehabilitative, and developmental. The booklet is a medium of guidance/learning that can attract interest and help teenagers understand the guidance material. This study aimed to determine the effect of the spiritual guidance of reproductive health care professionals by booklets on changes in adolescent attitudes towards dating status in premarital sexual behavior. A combination of qualitative and quantitative experimental research with a pre-experimental design, one group pretest-posttest, with a total sample of 26 adolescents, selected a purposive sampling technique. The spiritual guidance intervention used booklets for six meetings with 60-90 minutes each meeting within 2 months. Data were collected through pre-test and post-tests using interview sheets and Likert scale questionnaires. Data were analyzed qualitatively and statistically tests using the Wilcoxon test. The results showed that the sexual behavior of adolescents in dating was including holding hands, embracing the arms/shoulders and waist, hugging, kissing cheeks and lips, stroking the head, laying on the partner's thighs, and having sex with condoms. Then, from the statistical test, the negative ranks between the pre-test and post-test values were 0. Meanwhile, the positive ranks between the pre-test and post-test values indicated that 24 respondents with a positive value and a mean rank value of 13.00, and 2 respondents with a pre-post value remain the same. The Wilcoxon test shows the p-value (sig) $0.000<0.05$. Thus, the spiritual guidance of reproductive health care professionals using booklets significantly affected changes in adolescent attitudes towards dating status in premarital sexual behavior.
\end{abstract}

Keywords: Spiritual Guidance, Youth Reproductive Health Care, Guidance Booklet, Adolescent Attitude, Premarital Sex

https://doi.org/10.33860/jik.v15i2.463

(C) 2021 by the authors. Submitted for possible open access publication under the terms and conditions of the Creative Commons Attribution (CC BY SA) license (https://creativecommons.org/licenses/by-sa/4.0/). 


\section{INTRODUCTION}

According to $\mathrm{WHO}$, adolescence is a life stage of change or transition from childhood to adulthood in 10-19 years old. The regulation of the Minister of Health of the Republic of Indonesia number 25 states that adolescents are residents 10-18 years old. According to National Population and Family Planning Agency (in Indonesian is Badan Kependudukan dan Keluarga Berencana Nasional, abbreviated as BKKBN), the age range of adolescents is 1024 years old and unmarried ${ }^{1 \& 2}$. Teenagers tend to like and want to try new things, supported by various stimuli from outside bad influences, leading teenagers into premarital sexual behavior, which causes teenagers to be vulnerable to reproductive health problems, which are global problems, including Indonesian, such as teenage pregnancy. Unwanted behavior then prompted her to have an abortion, death during pregnancy and childbirth, contracting sexually transmitted diseases (STDs), and HIV-AIDS ${ }^{3}$.

The BKKBN (2015) shows that 48$51 \%$ of pregnant women are teenagers. As many as 800,000 cases were carried out in adolescents aged 15-19 years, and it is estimated that 2,000 teenagers have abortions ${ }^{4}$. Data from the Indonesian Child Protection Commission (in Indonesian is Komisi Perlindungan Anak Indonesia, abbreviated as KPAI) and the Ministry of Health in 2013, cases of HIV infection in 3 months were 10,203 cases, $30 \%$ of the sufferers were also teenagers ${ }^{5}$. In South Sulawesi Province in 2016, people with HIV/AIDS were categorized as teenagers aged 15-24 years, HIV was 213 cases, and AIDS was 104 cases. While the city of Makassar is also known for the increasing number of early marriages in 2018, what is concerning is that it turns out that most of those who apply for early marriage to the Religious Courts (in Indonesian is Pengadilan Agama, abbreviated as PA) are teenagers who have been pregnant before marriage ${ }^{6}$.

The Indonesian Demographic and Health Survey (2017) showed that dating activities became an entry point for premarital sex, giving birth to various risky practices. The survey showed that most of the teenage girls
( $81 \%)$ and teenage boys (84\%) had been in a relationship, most of them admitted that when they were dating, they did activities of holding hands, hugging, kissing lips, and touching ${ }^{7}$, and sexual intercourse ${ }^{8 \& 9}$.

Based on Sahrazi \& Arifin (2019) ${ }^{10}$, in Makassar, teenagers who are dating also engage in sexual activities to deviant sex. Among those 46 college students, they hold hands, hugging, dry kissing, wet kissing, petting/fingering, masturbation, fantasizing or imagining, and sex/intercourse. Responding to the problem in adolescents, the government has taken several steps to reduce and prevent premarital sexual relations. In fact, the number of premarital sex in adolescents has not experienced significant changes; some have even increased.

The many bad effects of premarital sexual relations from the perspective of the world of health make teenagers avoid the harmful effects of this activity. From another perspective, as a country with a Muslim majority, Indonesia already knows that in Islam, premarital sexual relations or adultery is an illegal behavior because it deviates from the rules of Allah SWT and brings badness to the perpetrator. Thus, it is important to present a guide for youth, which leads to a change in attitude by changing and creating the right mindset towards premarital sex in the spiritual aspect concerning health care, leading to an understanding of the laws and consequences premarital sex from an Islamic perspective.

Spiritual guidance is oriented towards strengthening moral values, the value of worship in addressing life, especially reproductive health issues. The approach includes several aspects: preventive, curative, and rehabilitative ${ }^{11 \& 12}$. Research from Qureshi et al., (2018) ${ }^{13}$ states that CAM practitioners and most people worldwide give a positive response, including a great interest in spiritual guidance due to various dynamic forces, including positive effects on health, sense of well-being, and improving quality of life. The lack of a spiritual aspect in a person, especially teenagers, will create thoughts and feelings that do not want to be bound by God's rules. Finally, the freedom to behave without control leads to bad things that impact reproductive health problems. 
In guidance, learning/guidance media is needed as a guide to facilitate the mentoring process. The results of research from Schiller stated that the provision of booklets is an educational/guidance approach that can significantly increase knowledge and interest in adolescents $^{14 \& 15}$. Thus, it takes a step to control premarital sexual behavior among teenagers and attract them to take part. So this study aimed to assess the effect of spiritual guidance on reproductive health using booklets on changes in adolescent attitudes towards dating status in premarital sexual behavior.

\section{MATERIALS AND METHODS}

\section{Location and Research Design}

This research was conducted at one of the campuses in Makassar, State University of Makassar. This research was a combination of qualitative and quantitative experimental research, a pre-experimental design with one group pretest-posttest.

\section{Population and Sample}

The population in this study were all active students in the Sociology Education Study Program (Faculty of Social Science), Semester II, IV, and VI, State University of Makassar, 231 students. The sampling technique used in this study was a purposive sampling technique that met the inclusion criteria, including adolescents girls aged 18-24 y.o, Muslim, unmarried, currently in a dating, and willing to be respondents. The sample obtained in this study was 26 students.

\section{Collecting data}

This study used two instruments. First, an interview sheet that contained open and systematic questions to record the interview process at the beginning of the meeting. Second, the pre-test and post-test sheets were in the form of a Likert Scale questionnaire to measure attitudes/opinions towards a statement. This questionnaire contained 10 statements with 5 statements for favorable items and 5 statements for unfavorable items using a scoring technique. Measurements were carried out before and after the intervention was carried out face-to-face and through virtual video calls.

\section{Data Analysis}

Data analysis was carried out on data obtained from interviews and pre-post tests. Analysis of the results of the interviews was carried out qualitatively as a narrative description of the data. Meanwhile, the test results used univariate quantitative analysis to summarize pre-test and post-test data distribution from descriptive statistics. Bivariate analysis was used to test hypotheses and determined the effect between two variables, the independent and dependent variables and tent able, by SPSS version 24 for Windows. The test used was a paired T-test parametric analysis. However, a nonparametric Wilcoxon test would be carried out under the normal distribution data if the data obtained was not homogeneous

\section{RESULTS}

Table 1 shows that the motivation of adolescents for dating is the feeling of being close to someone as a social being, filling free time, and having fun, and the matchmaking factor. Then, Most of the informants had a frequency of meeting with their partners, 3 to 5 times a week.

Table 2 shows that most respondents changed attitude before and after the intervention. Respondents with a positive attitude before the intervention were 15 (57.69\%) to 10 (38.46\%), which means 5 people changed their attitude to be very positive after the intervention. Furthermore, very positive attitude was 2 persons (7.69) before the intervention also increased to 16 persons $(61.54 \%)$ after the intervention. The number mostly came from respondents with a negative attitude (1 person/3.84\%) and very negative attitude (8 persons $/ 30.78 \%)$ before the intervention, which changed to 0 respondents after the intervention. It means that the attitude of the respondents changed to be positive and very positive after the intervention.

Based on Table 3, the results of the Wilcoxon test analysis showed that the negative rank between the pre-test and post-test scores of attitudes was 0 , which indicated no reduction from the pre-test to the post-test. Moreover, the positive ranks between the pre-test and post-test values of attitudes indicated that 24 persons with positive scores on adolescent attitudes. 
The 24 adolescents experienced an increase in attitude, with a mean rank value of 13.00. In addition, there were 2 teenagers with the same pre-test and post-test attitude scores. The statistical test results showed a p-value (sig) of $0.000<0.05$, which means that the use of booklets had a significant effect on adolescents' attitudes with dating status in premarital sexual behavior

Table 1 Interview Conclusions

Question Items Interview Conclusion

1. What is the motivation for dating?

2. How many meetings and walking together in a week with the partner?

3. In dating, what activities are usually done with a partner?

\begin{abstract}
Teenagers who were dating, driven mainly by feelings or instincts as social beings who want to be close to someone who understood, loved, supported, and struggled with problems. Then, another thing that encouraged teenagers' motivation in dating was to fill spare time and have fun, for example, getting treats to eat, traveling with economical costs, and others. In addition, some followed their friends, but in the end, they fell into ongoing dating. It was different with one respondent who turned out to be in an early relationship due to an arranged marriage from the family and then continuing dating. However, the time for marriage was still quite long, about one year to wait for the completion of the study.
\end{abstract}

Most of the informants had a frequency of meeting with their partner, 3 to 5 times a week. Also, 3 informants we're meeting only once a week because the online lectures made them prefer to return to their hometown, created difficulty in a direct meeting with a partner, and chose a video call only.

About 3 informants admitted that their activities were only limited to eating, watching, and holding hands. The other informants were hugging the arm/shoulder/waist hugs, forehead kisses, hair stroking, cheek kisses, lying on their partner's thighs, and lip kisses because a partner forced them. Then, 3 people claimed a request from their partner to have sex but refused in their way. There was 1 informant who claimed to have sex but used a contraceptive. In addition, 6 informants often visited their respective boarding houses between couples. Some watched together in their room, and some joined other friends.

Table 2 Summary of the Frequency Distribution of Attitude Values Based on Respondents' Tests Before and After Being Given Health Care Spiritual Guidance

\begin{tabular}{|c|c|c|c|c|c|}
\hline \multirow{2}{*}{ No. } & \multirow{2}{*}{ Attitude Category } & \multicolumn{2}{|c|}{ Pre Test } & \multicolumn{2}{|c|}{ Post Test } \\
\hline & & $n$ & $\%$ & $n$ & $\%$ \\
\hline 1. & Very Positive & 2 & 7,69 & 16 & 61,54 \\
\hline 2. & Positif & 15 & 57,69 & 10 & 38,46 \\
\hline 3. & Negative & 8 & 30,78 & 0 & 0 \\
\hline 4. & Very Negative & 1 & 3,84 & 0 & 0 \\
\hline & Total & 26 & 100 & 26 & 100 \\
\hline
\end{tabular}

Table 3 Wilcoxon Attitude Test Results Pre-Post

Test

\begin{tabular}{llll}
\hline Attitude Value Pre-Post Test & $\boldsymbol{N}$ & Mean Rank & P-Value (Asymp Sig) \\
\hline Negative Ranks & 0 & 0,00 & 0,000 \\
Positive Ranks & 24 & 13,00 & \\
Ties & 2 & & \\
Total & 26 & & \\
\hline
\end{tabular}




\section{DISCUSSION}

The process of carrying out the research began with conducting open interviews to obtain information related to sexual behavior during dating or relationship, then giving a pretest and obtaining the treatment of spiritual health guidance for 6 meetings with a duration of 60-90 minutes each meeting using the media booklet, entitled "Guidance Materials: For You Teenagers" which contains 7 materials. The guidance was conducted direct face-to-face and through virtual video calls. Not all respondents had the same meeting schedule and method since the guidance was adjusted to the respondent's lecture schedule. After the guidance meetings were completed, the respondents did a post-test on the last day of the guidance meeting.

Based on the interviews, the dating carried out by teenagers came from the motivation to have a partner to please, just for fun, to go along with friends. Then, finally, the friendship continued in dating. Most of the respondents admitted that the frequency of meeting their partners mainly about 3-5 times a week which influenced the sexual behavior of teenagers. Of the 26 respondents, most obtained information that the behavior carried out during meetings with girlfriends was walking and eating together, watching movies, and including boarding/residential visits. Then other activities were holding hands, hugging and embracing arms, forehead and cheek kisses, head caressing, and deeper behaviors are lip kissing, lying on the partner's thighs, and entering into intimate sexual intercourse (coitus) using condoms.

The various behaviors of adolescents during dating, according to the interview, were in line with the Indonesian Demographic and Health Survey (IDHS) finding in 2017. It shows that dating activities have become an entry point for premarital sex, giving birth to various risky practices. The survey showed that most teenage girls $(81 \%)$ and teenage boys $(84 \%)$ were in a relationship. Most admitted that when dating, they held hands, hugged, kissed on the lips, and felt/touched ${ }^{7}$. So looking at the data obtained, the researchers continued providing interventions to determine and change respondents' attitudes towards premarital sex behavior in relationships.

Then, based on the results of the frequency distribution of the attitude values of the respondents, it was found that the spiritual guidance for reproductive health and safety by using booklets made a difference before and after the intervention and had a significant effect on changes in adolescent attitudes towards dating status in premarital sexual behavior. Based on the analysis results, the respondents' attitudes before and after the intervention showed that most of them experienced a change in attitude. Respondents with a positive attitude before the intervention were 15 persons (57.69\%) to 10 persons (38.46\%), which means 5 persons changed their attitude to be very positive after the intervention because there were no negative and very negative attitudes (0\%). Furthermore, very positive attitudes before the intervention were 2 persons (7.69) also increased to 16 persons $(61.54 \%)$. It mostly came from respondents with a negative attitude of 1 person $(3.84 \%)$ and very negative of 8 people (30.78\%) before the intervention.

Adolescent sexual behavior is a form of reflection of the growth and development experienced by adolescents. So spirituality can be a factor to create steps for adolescents in responding to sexual behavior with a positive attitude16. Positive sexual behavior means understanding correctly and appropriately in attitudes and determining actions in understanding sexual health ${ }^{17 \& 18}$.

The results obtained by researchers are in line with several research results including the results of research from Kuswatun et al, tahun $(2021)^{19}$ who concludes from the results of his research, can show that spiritual guidance with CBT shows a change in the respondent's state of mind from an apparent negative attitude to a positive attitude and behavior, which means this approach can change the cognitive and behavior of adolescents. There are also research results from Wahidin in (2017) $)^{20 \& 21}$ conducted in adolescence, states that adolescents who are close to spiritual life will more easily take a positive attitude than those who are far from spiritual life, in other words, the higher the spirituality, the higher the positive attitude in 
adolescents.

Furthermore, the results of research from Burkina Faso, West Africa by Soura et al $(2018)^{22}$ which compares several factors that cause premarital sex including age, religion (Islam with other religions), the role of women, and culture, the results show that the risk of free sex is low in Muslim women who understand their religion correctly compared to other factors that are high be a risk factor for promiscuity. Seeing the positive effects of this spiritual understanding, it will certainly be one of the steps that can prevent and protect adolescents, especially women, from reproductive health problems. Then research by Muhammad et al, (2016) ${ }^{23}$, A self-administered questionnaire survey to determine the relationship between religiosity and adolescent sexual activity included 1026 university students recruited from 12 randomly selected universities in the Klang Valley, Malaysia. Both quantitative and qualitative results were then compared and integrated and it was found that religious activity significantly reduces the risk for adolescents to continue sexual activity and that engaging in religious activities is effective in preventing female students from being sexually active.

Meanwhile, the differences in attitudes taken by adolescents before and after giving guidance with a p-value (sig) were $0.000<0.05$. It can be concluded that there was a significant difference before and after the intervention and spiritual guidance of reproductive health care by using the booklet, significantly affect changes in adolescent attitudes towards dating status in premarital sexual behavior. Attitudes can be formed or changed because of the stimulus that affects a person. The formation or change of attitude is a person's response to the stimulus he receives.

One such stimulus can come from spiritual guidance, where religion has proper boundaries for organizing life and can direct one's attitude. Spiritual guidance related to spiritual aspects associated with reproductive health will touch the heart/soul and mind. There is a belief in a relationship with the Almighty and the Creator, which will give birth to an attitude to carry out God's commands, such as to do right and stay away from evil, including maintaining reproductive health properly.

These results are in line with several previous findings that spiritual guidance influences changes in attitudes and behavior. Widarna and Putri (2019) ${ }^{12}$ compare spiritual counseling and behaviorism approach counseling in preventing premarital sex in adolescents; it turns out that spiritual guidance is most effective and can affect adolescent attitudes. Spiritual knowledge is closely related to the mindset that will affect a person's attitude and behavior; instilling the spiritual aspect will slowly change negative behavior towards better behavior $^{24}$. This is in line with Raharjo $(2014)^{25}$; the better the spiritual intelligence, the more teenagers behaved unsupportive of premarital sex behavior that could harm themselves and others.

Meanwhile, the booklet is an educational approach that can significantly increase students' knowledge of certain goals. This is in line with the results of several other studies showing the effectiveness of booklets, including the results of research from Susilowati in $(2016)^{14}$, which stated that the provision of booklets is an educational/guidance approach that can significantly increase knowledge and interest in adolescents. Research from Pratiwi (2017) ${ }^{26}$ shows that the booklets significantly affect the level of knowledge and attitudes of HIV and AIDS prevention in adolescent students. Besides, Mieke (2017) ${ }^{27}$ concludes that booklet media effectively increased the knowledge and attitudes of one of the high schools in Pontianak (SMA Santun, Universitas Tanjungpura Pontianak) students related to the impact of pornography.

The implication of this research was to provide the correct mindset for adolescents in viewing premarital sex behavior, giving the effect of changing attitudes that can prevent premarital sex behavior, which was a behavior that contributes to reproductive health problems for adolescents. So, the researcher assumes that the spiritual guidance of health care for teenagers deserves to be one of the steps that can be used to prevent premarital sex among teenagers.. 


\section{CONCLUSION AND SUGGESTION}

Most adolescent activities during dating were to have sexual behavior that can stimulate premarital sex. After being given guidance, adolescents experienced a more positive attitude change based on awareness of the role of God in life, including in the reproductive system, and there was a significant effect of providing spiritual guidance on health and sex with the use of booklets on attitude changes in adolescent sexual behavior with dating status. So further, it is suggested that spiritual guidance can be one of the routine activities for teenagers to improve Islamic spiritual knowledge. Then, it can still be a guide in dealing with and avoiding premarital sex deviant behavior and can be a source of input in the discussion in the development of solutions related to preventive efforts in premarital sexual behavior to maintain adolescent reproductive health.

\section{REFERENCE}

1. Ministry of Health, RI. (2015). Infodatin: The situation of adolescent reproductive health . South Jakarta: Data and Information Center of the Indonesian Ministry of Health .

2. Wellisch, L., \& Chor, J. (2015). Adolescent Girls and Abortion. PEDIATRIC ANNALS, 44. https://doi.org/10.3928/00904481-2015091012

3. Lestari, P., Pratiwi, E. A. \& Wasliah, I. (2019). Adolescent Knowledge of Premarital Sexual Behavior. Journal of Pediatric Nursing. https://doi.org/http://dx.doi.org/10.32584/jika. v0i0.360.

4. Misrina, \& Safira, S. (2020). The Relationship Of Knowledge And Adolescent With Premarital Sex Behavior In Middle School Of 2 Mereudu District Meurah Two Pidie Jaya District . Journal of Healthcare Technology and Medicine Universitas Ubudiyah Indonesia , 6 .

5. Ministry of Health, RI. (2018). InfoDatin: The General Situation of HIV/AIDS . South Jakarta: Data and Information Center of the Indonesian Ministry of Health.

6. Profile of the South Sulawesi Provincial Health Office. (2017). Profile of the South Sulawesi Provincial Health Office 2017.

7. BKKBN. (2017). Demographic and Health Survey: Adolescent Reproductive Health 2017. National Population and Family Planning Agency,1-606. http://www.dhsprogram.com.
8. Manning, W.D., Longmore, A.A., Copp, J., \& Giordano, P.C., (2014). The Complexities of Adolescent Dating and Sexual Relationship: Fluidity, Meaning(s), and Implications for Young Adults' Well-Being. New Dir Child Adolesc. 10.1002/cad.20060

9. Parmawati, I., Nisman, W.A., Lismidiati, W., \& Mulyani, S. (2020). Efforts to Reduce Premarital Sexual Activities Through Gender Equality-Based Reproductive Health Education. Indonesian Journal of Community Engagement. http://doi.org/ 10.22146/jpkm.38144

10. Sahrazi, A. R. \& Arifin, Z. (2019). Student Dating Sexual Behavior Case Study at the Faculty of Social Sciences, Makassar State University. Journal of Sociology Education Socialization-FIS UNM. https://ojs.unm.ac.id/socialization/article/view File/13346/7812

11. Wilda, E. (2019). Islamic Counseling (2nd Edition). Yogyakarta: Psychosine.

12. Putri, D. W. L. \& Sanaputri, R. (2019). Premarital Sex and its Handling Behavioral Perspectives and Islamic Counseling. Qawwam $\quad 13$ https://doi.org/https://doi.org/10.20414/qawwa m.v13i2.1730

13. Qureshi, N. A., Khalil, A. A., Alsanad, S. M. (2018). Spiritual and Religious Healing Practices: Some Reflections from Saudi National Center for Complementary and Alternative Medicine, Riyadh. Journal of Religion and Health. https://doi.org/10.1007/s10943-018-0677-0

14. Susilowati, D. (2016). Health Promotion (Print Nursing Teaching Materials Module) (1st CET). Jakarta: Health Human Resources Center.

15. Schiller, Y., Schulte, K. G., Eberle, S. R., Maier, B., \& Allgaier, A.-K. (2013). Increasing Knowledge About Depression in Adolescents: Effects of an Information Booklet. Social Psychiatry and Psychiatric Epidemiology, 49. https://doi.org/https://doi.org/10.1007/s00127013-0706-y

16. Aridona, J. (2017). The Relationship Between Spiritual Intelligence And Emotional Maturity With Adjustment In Adolescents. ISSN:25484044. Psychoislamedia Journal of Psychology.

17. Darmawan, A. I. \& Wardhaningsih, S. (2020) . Spiritual Roles Related to Adolescent Social and Sexual Behavior. Journal of Mental Nursing FIKKes University of Muhammadiyah and PPNI Central Java. DOI: https://doi.org/10.26714/jkj.8.1.2020.75-82 
18. Suwarni, L., \& Selviana. (2015). Adolescent Premarital Sex Initiation and Influencing Factors. Journal of Public Health. https://doi.org/10.15294/kemas.v10i2.3378

19. Kuswatun, E., Nurjannah, N. \& Depriansya, D. (2021). Islamic Counseling With Cognitive Behavioral Therapy (Cbt) Approach To Overcome Juvenile Delinquency . Journal of Contemporary Islamic Counseling . ISSN (p): 2776-6470. ISSN (e): 2776-6586. https://alisyraq.pabki.org/index.php/jcic/

20. Wahidin , (2017) . Spirituality and Happiness in Late Adolescence and Its Implications in Guidance and Counseling Services . Journal of Innovative Counseling: Theory, Practice \& Research https://umtas.ac.id/journal/index.php/innovati ve counseling/

21. Tumanggor, R. O. \& Mularsih, H. (2020). Relationship of Spiritual Well-Being and Emotional Intelligence on Tolerance for Adolescents. Journal of An-Nafs: Psychological Research Studies Vol. 5. DOI:10.33367/psi.v5i2.958

22. Soura, A. B., Lankoande, Y. B., Sanogo, S., Compaore, Y. \& Senderowicz, L. (2018) Understanding premarital pregnancies among teenagers and young women in Ouagadougou, Burkina Faso. Cogent Social Sciences.Https://doi.org/10.1080/23311886.20 18.1514688

23. Muhammad , N. A., Shamsuddin, K., Sulaiman, Z., Amin, R. R. \& Omar, K. (2016). Role of Religion in Preventing Youth Sexual Activity in Malaysia: A Mixed Methods Study . A Journal of Religion and Health . DOI: 10.1007/s10943-016-0185-Z

24. Ghaffari, M., Gharghani, Z. G., Mehrabi, Y., Ramezankhani, A. \& Movahed, M. (2016). Premarital Sexual Intercourse-Related Individual Factors Among Iranian Adolescents: A Qualitative Study Iran. Red Crescent Med J. doi: 10.5812/ircmj.21220

25. Raharjo, S. S. ( 2014). The Influence of Spiritual and Environmental Intelligence on Adolescent Attitudes About Premarital Sex at Smk Batik 1 Surakarta. Prodi.Kedokteran Keluarga UNS Pascasarjana.

26. Pratiwi, D. A. (2017). The Effectiveness of Giving Booklets Towards Knowledge Levels And Attitudes To Prevent Hiv And Aids In Adolescents Of Class VIII Students At Smpn 1 Cangk Lightweight Sleman. Program Studi Bidan Pendidik Jenjang Diploma IV Fakultas Ilmu Kesehatan Universitas 'Aisyiyah Yogyakarta
27. Mieke, D. N. (2017). The Effectiveness of Media Booklets About the Impact of Pornography on Knowledge and Attitudes of Santun Untan Pontianak High School Students. Program Studi Kesehatan Masyarakat, Fakultas Ilmu Kesehatan, Universitas Muhammadiyah Pontianak 